\title{
Emissions and characteristics of particulate matter from rainforest burning in the Southeast Asia
}

\author{
Min Cui ${ }^{\mathrm{a}}$, Yingjun Chen ${ }^{\mathrm{a}, \mathrm{e}, *}$, Mei Zheng ${ }^{\mathrm{b}, * *}$, Jun $\mathrm{Li}^{\mathrm{c}}$, Jiao Tang ${ }^{\mathrm{c}}$, Yong Han ${ }^{\mathrm{a}}$, Debin Song ${ }^{\mathrm{d}}$, \\ Caiqing Yan ${ }^{\mathrm{b}}$, Fan Zhang ${ }^{\mathrm{a}}$, Chongguo Tian ${ }^{\mathrm{d}}$, Gan Zhang ${ }^{\mathrm{c}, * * *}$ \\ ${ }^{a}$ Key Laboratory of Cities' Mitigation and Adaptation to Climate Change in Shanghai (CMA), College of Environmental Science and Engineering, Tongji University, \\ Shanghai 200092, PR China \\ ${ }^{\mathrm{b}}$ SKL-ESPC and BIC-EAST, College of Environmental Sciences and Engineering, Peking University, Beijing 100871, PR China \\ ${ }^{\mathrm{c}}$ State Key Laboratory of Organic Geochemistry, Guangzhou Institute of Geochemistry, Chinese Academy of Sciences, Guangzhou Guangdong 510640, PR China \\ ' Yantai Institute of Coastal Zone Research, Chinese Academy of Sciences, Yantai 264003, PR China \\ e Shanghai Institute of Pollution Control and Ecological Security, Shanghai 200092, PR China
}

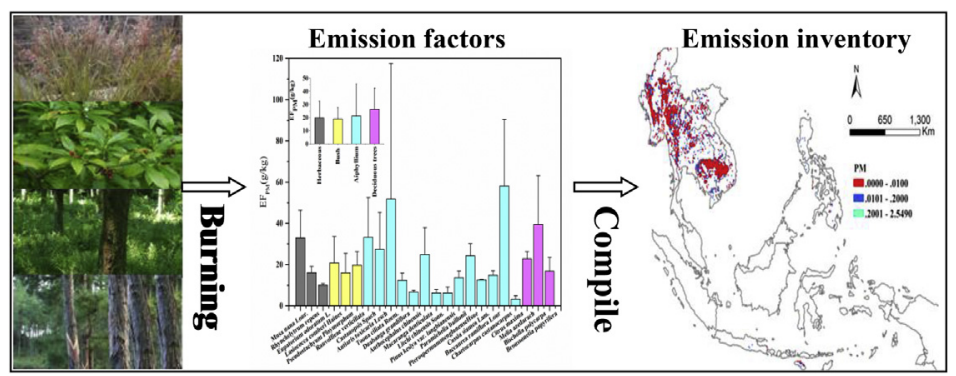

A R T I C L E I N F O

\section{Keywords:}

Southeast Asia

Emission factors

Rainforest burning

Particulate matter

Emission inventory

\begin{abstract}
A B S T R A C T
The burning of tropical rainforests in the Southeast Asia emits considerable particulate matter (PM), which has significant effects on air quality and human health. Lacking of reliable local $\mathrm{EF}_{\mathrm{PM}}$ for rainforest burning in the Southeast Asia is one of the most important causes for uncertainty of the estimated pollutant emissions. In this study, 23 types of rainforest plants, including herbaceous, shrubs, evergreen trees and deciduous trees were burned to determine emission factors of PM and multiple chemical species, including organic carbon (OC), elemental carbon (EC), water soluble ions (WSIs), and elements using a custom-made dilution system. $\mathrm{EF}_{\mathrm{PM}}$ for the four vegetation types was relatively higher for burning of deciduous trees, followed by evergreen trees, shrubs and herbaceous. $\mathrm{EF}_{\mathrm{PM}}$ in the Southeast Asia was higher than those in the North America, South America and Africa, with biomass type and ambient temperature and humidity as the determinant factors. Organic matter was the dominant constituent of PM, accounting for 57\%, followed by EC, WSIs and elements. Source profile of WSIs varied larger than those of OC, EC and elements for different biomass type and areas. For example, the fraction of $\mathrm{K}^{+}$, a typical biomass burning tracer, to WSIs was 30\% and $28 \%$ in the Southeast Asia and North America, respectively, which was almost 2 times lower than those in the Europe. Finally, the temporal and spatial scales of PM, OC, and EC emissions from rainforest burning in the Southeast Asia in 2016 were estimated,
\end{abstract}

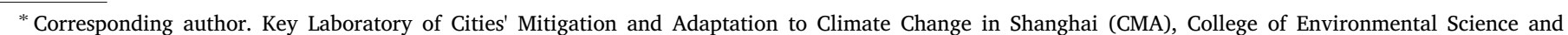
Engineering, Tongji University, Shanghai 200092, PR China.

** Corresponding author.

***⿰㇇⿰亅⿱丿丶丶 Corresponding author.

E-mail addresses: yjchentj@tongji.edu.cn (Y. Chen), mzheng@pku.edu.cn (M. Zheng), zhanggan@gig.ac.cn (G. Zhang). 
based on the updated measured EFs. The annual emissions (minimum-maximum) were 1527-2834 Gg, 529.9-1100 Gg, and 81.02-150.4 Gg for PM, OC and EC, respectively. Our results suggest that using of $\mathrm{EF}_{\mathrm{PM}}$ reported in other regions would lead to an underestimation of PM emissions in the Southeast Asia.

\section{Introduction}

Tropical rainforest is one of the most important global ecosystems, which plays an important role in global climate change, air quality, and ecosystem material cycles (Burgess et al., 2017, Liu et al., 2017a, $2017 b, 2017 c)$. Forest fires occur each year due to anthropogenic and natural factors. Large amounts of particulate matter are emitted from these fires, with significant adverse impacts on human health and air quality (Jian and Fu, 2014). As estimated by Andreae and Merlet (2001), the global PM emissions from tropical rainforests fires were about $11.3 \mathrm{Tg}$ per year, accounting for about $13.7 \%$ of the total emissions from biomass burning.

There are three tropical rainforest systems in the world, geologically distributed in the Africa, South America, and Southeast Asia. Among which, Southeast Asia has been recognized as one of the most active areas for forest fires detected by moderate resolution imaging spectroradiometer (MODIS). Southeast Asia (e.g., Afghanistan, Bangladesh, Bhutan, India, Maldives, Nepal, Pakistan, and Sri Lanka) covers an area of $1.9 \times 10^{6} \mathrm{~km}^{3}$ of rainforest, which accounts for almost $42 \%$ of its total land area. Streets et al. (2003) reported that the burning of biomass in tropical forest fires accounted for $73 \%$ of the total burning activities every year in the Southeast Asia. Furthermore, recent studies have demonstrated that forest burning is the most important source of air pollution in the Southeast Asia (Reddington et al., 2014; Lee et al., 2017) causing significant health and climate impacts. Epidemiological studies have shown that emissions from biomass burning in the Southeast Asia result in 10,800 deaths per year (Reddington et al., 2014). The pollutants emitted from biomass burning in the Southeast Asia might be transported to areas far away from their source, such as China, and may then exert significant effects on global climate change (Chan, 2017; Chan and Chan, 2017). It was reported that more than $50 \%$ of the BC deposition on Tibetan glaciers can be influenced by biomass burning (including agricultural waste burning and wildfires) during the non-monsoon season in the South Asia (Zhang et al., 2017).

Accurate pollutant emissions factors are imperative for estimating emissions inventories and conducting air quality assessments. Three methods are commonly used to measure EFs of air pollutants emitted from forest burning, including laboratory measurements, field measurements (sampling plume directly at biomass burning site), and plume tracking (monitoring at the downwind of the burning site) (Alves et al., 2011; Amaral et al., 2016; Hsieh et al., 2016). Considering the dangers of field measurements and the excessive costs of plume tracking, open burning simulation study is an optimal choice for investigating emission characteristics from burning different types of rainforest plants. Dating back to the 1990s, real-world measurements of pollutant EFs from forest fires were mainly conducted on the regions such as Amazon Plain, African Plain, and the United States (Watson et al., 2001; Christian et al., 2003; Sinha et al., 2003; Akagi et al., 2011; Chow et al., 2011). Unfortunately, little studies have been conducted to characterize the rainforest burning in the Southeast Asia (Chaiyo and Garivait, 2014; Sen et al., 2014).

By combining satellite images with pollutant EFs, emission inventories of different pollutants from rainforest burning in the Southeast Asia have been compiled in many studies (Andreae and Merlet, 2001; Chang and Song, 2010; Chaiyo and Garivait, 2014; Shi et al., 2014; Shi and Yamaguchi, 2014; Streets et al., 2003). However, the accuracy and timeliness of the EFs in these studies should be updated. Currently, there are several types of satellite products for assessing the burned areas, including the global fire emission database (GFED), MODIS, and L3JRC. Among which, MODIS has been demonstrated to be more accurate than the other two products (Chang and Song, 2010). However, emission inventories of PM developed in previous studies in the Southeast Asia were usually based on EFs determined from other tropical regions, which would increase the uncertainty of PM emissions. For example, the PM EFs $\left(\mathrm{EF}_{\mathrm{PM}}\right)$ measured in other regions summarized by Andreae and Merlet (2001) are still used to estimate the emissions inventory in the Southeast Asia till now without consideration of regional differences in fuel types and meteorological/burning conditions (Duncan et al., 2003; Giglio et al., 2013). It is crucial to evaluate whether there are differences in emission

Table 1

Detail information of elements in rainforest vegetation (\% dry weight).

\begin{tabular}{|c|c|c|c|c|c|c|c|}
\hline Categories & Fuel name & Moisture & $\mathrm{N}$ & $\mathrm{C}$ & $\mathrm{H}$ & $\mathrm{O}$ & $\mathrm{C}$ in ash \\
\hline \multirow[t]{3}{*}{ Herbaceous } & Musa nana Lour. & 9.33 & $1.92 \pm 0.57$ & $45.8 \pm 1.76$ & $5.71 \pm 0.69$ & $41.3 \pm 7.94$ & $16.0 \pm 5.56$ \\
\hline & Rhynchelytrum repens & 8.73 & $0.97 \pm 0.05$ & $42.3 \pm 0.17$ & $5.96 \pm 0.001$ & $38.5 \pm 0.26$ & $12.0 \pm 1.28$ \\
\hline & Eupatorium odoratum L. & 12.42 & $0.95 \pm 0.18$ & $46.0 \pm 0.12$ & $5.4 \pm 0.34$ & $50.6 \pm 0.05$ & $52.8 \pm 7.54$ \\
\hline \multirow[t]{3}{*}{ Shrubs } & Lasiococca comberi Haines & 10.70 & $0.71 \pm 0.18$ & $44.0 \pm 0.35$ & $6.56 \pm 0.15$ & $46.7 \pm 0.28$ & $14.4 \pm 0.594$ \\
\hline & Pseudostachyum Ploymorphum & 10.11 & $0.65 \pm 0.02$ & $48.7 \pm 0.09$ & $7.27 \pm 0.05$ & $47.5 \pm 0.42$ & $64.4 \pm 10.6$ \\
\hline & Rauvolfieae verticillata & 12.01 & $0.41 \pm 0.01$ & $48.6 \pm 0.17$ & $5.9 \pm 0.02$ & $49.3 \pm 0.33$ & $64.8 \pm 10.1$ \\
\hline \multirow[t]{14}{*}{ Evergreen trees } & Castanopsis Spach & 10.78 & $0.78 \pm 0.022$ & $48.1 \pm 0.12$ & $6.19 \pm 1.17$ & $46.5 \pm 0.18$ & $35.7 \pm 2.95$ \\
\hline & Antiaris toxicaria Lesch & 13.75 & $1.5 \pm 0.0$ & $47.8 \pm 0.21$ & $6.28 \pm 1.05$ & $45.6 \pm 0.28$ & $66.9 \pm 3.37$ \\
\hline & Toona ciliata Roem. & 11.27 & $0.32 \pm 0.01$ & $49.4 \pm 0.43$ & $5.97 \pm 0.14$ & $45.5 \pm 0.12$ & $65.7 \pm 13.0$ \\
\hline & Duabanga grandiflora & 9.76 & $0.19 \pm 0.27$ & $48.4 \pm 0.31$ & $6.69 \pm 0.27$ & $44.5 \pm 0.67$ & $68.4 \pm 9.39$ \\
\hline & Anthocephalus chinensis & 9.49 & $0.33 \pm 0.01$ & $48.6 \pm 0.11$ & $5.86 \pm 0.09$ & $49.7 \pm 0$ & $81.7 \pm 4.39$ \\
\hline & Macaranga denticulata & 11.07 & $0.46 \pm 0$ & $44.4 \pm 0.53$ & $5.79 \pm 1.22$ & $44.5 \pm 0.90$ & $50.2 \pm 7.17$ \\
\hline & Litchi chinensis Sonn. & 12.46 & $0.66 \pm 0.01$ & $50.9 \pm 0.35$ & $5.68 \pm 0.40$ & $44.8 \pm 0.10$ & $86.0 \pm 0.042$ \\
\hline & Pinus kesiya var. langbianensis & 10.77 & $0.2 \pm 0.28$ & $47.9 \pm 0.32$ & $5.91 \pm 0.40$ & $47.7 \pm 0.13$ & $83.6 \pm 0.163$ \\
\hline & Paramichelia baillonii & 9.75 & $1.6 \pm 0$ & $45.34 \pm 0.09$ & $5.7 \pm 0.01$ & $43.93 \pm 0.78$ & $35.1 \pm 7.19$ \\
\hline & PterospermummenglunenseHsue & 13.62 & $0.21 \pm 0.30$ & $38.9 \pm 0.04$ & $5.47 \pm 0.30$ & $49.12 \pm 0.09$ & $27.2 \pm 10.9$ \\
\hline & Cassia siamea Lam. & 10.50 & $0.62 \pm 0.12$ & $45.7 \pm 0.04$ & $6.28 \pm 1.37$ & $43.8 \pm 0.14$ & $25.6 \pm 3.77$ \\
\hline & Baccaurea ramiflora Lour & 12.94 & $0.69 \pm 0.02$ & $47.3 \pm 0.06$ & $5.83 \pm 1.20$ & $48.1 \pm 0.05$ & $43.1 \pm 6.73$ \\
\hline & Chaetocarpus castanocarpus & 22.62 & $0.86 \pm 0.02$ & $49.6 \pm 0.12$ & $6.87 \pm 0.09$ & $46.1 \pm 0.23$ & $77.9 \pm 1.64$ \\
\hline & Citrus maxima & 8.84 & $0.73 \pm 0$ & $49.6 \pm 0.09$ & $5.73 \pm 0.01$ & $23.7 \pm 30.8$ & $77.1 \pm 1.72$ \\
\hline \multirow[t]{3}{*}{ Deciduous trees } & Melia azedarach & 13.12 & $0.00 \pm 0.00$ & $47.8 \pm 0.14$ & $6.12 \pm 0.04$ & $48.7 \pm 0.3$ & $64.8 \pm 11.2$ \\
\hline & Bischofia polycarpa & 10.34 & $0.49 \pm 0.0$ & $47.1 \pm 0.08$ & $5.53 \pm 0.13$ & $50.2 \pm 0.95$ & $50.6 \pm 12.3$ \\
\hline & Broussonetia papyrifera & 10.55 & $0.72 \pm 0.02$ & $45.7 \pm 0.11$ & $5.32 \pm 0.02$ & $55.8 \pm 15.7$ & $55.3 \pm 28.6$ \\
\hline
\end{tabular}


factors and characteristics of PM as well as its constituents in emissions from different tropical rainforest regions worldwide and examine how much difference between them.

The objectives of this study are 1) to measure emission factors of PM and its constituents for various types of tropical rainforest vegetation in the Southeast Asia based on a real-world open burning experiment, 2) to compare emission factors of PM and its compositions from rainforest burning in the Southeast Asia and other tropical regions worldwide, and 3) to estimate emissions of PM, organic carbon, and elemental carbon from tropical rainforest burning in the Southeast Asia in 2016 on temporal and spatial scales.

\section{Methodology}

\subsection{Sampling}

Pollutant emissions from forest burning, as a special form of combustion, are difficult and dangerous to measure in the field. Thus, an open burning experiment was designed to carefully simulate the burning of tropical rainforest in the field. The open burning experiments were carried out in 2016 during summer in Yunnan province, China where ambient conditions were identical with those in the Southeast Asia. Twenty-three Southeast Asian tropical rainforest plants were collected, and the detailed information of these plants was given in Table 1. Generally, these 23 tropical rainforest plants were classified into four types including herbaceous plants, shrubs, evergreen trees, and deciduous trees. Raw materials were air-dried for several days, and the size of plants was approximately $20 \times 3 \times 2 \mathrm{~cm}^{3}$ to fit in the combustion installation.

First, homologous wood was used for ignition in a 40-cm-diameter stainless-steel bowl, which was combusted with sufficient air supply. Then well-prepared fuel log collected directly from rainforest in the Southeast Asia was added to the combustion stainless steel plate. Finally, the smoke was collected through a self-designed dilution system. The sampling system consisted of a dilution tunnel, a residence time chamber, three PM samplers, an Andersen 8-stage sampler, and several temperature and humidity sensors (Fig. 1). Every plant type was burned three times, approximately $1-2 \mathrm{~kg}$ of fuel per burn. Fuel and ash were weighed before and after combustion. Quartz filters for PM sampling were prebaked at $450{ }^{\circ} \mathrm{C}$ for $4.5 \mathrm{~h}$ before sampling and were then stored in a refrigerator at $-20^{\circ} \mathrm{C}$ after sampling prior to analysis.
Dilution ratios of each experimental process were calculated using the $\mathrm{CO}_{2}$ concentrations before and after dilution.

\subsection{Chemical analysis}

Before and after sampling, the filters were conditioned at $25{ }^{\circ} \mathrm{C}$ and $40 \%$ relative humidity for $24 \mathrm{~h}$ before weighing. Then filters were weighed using a Mettler-Toledo electronic analytical balance with a precision of $10^{-4} \mathrm{~g}$. The PM concentration was determined gravimetrically. Next, filters were used for the analysis of various PM chemical components, including OC, EC, water soluble ions, and multiple elements. The detailed analytical protocols have been described previously (Zong et al., 2015, Cui et al., 2016, 2017). Briefly, a punch with $0.544 \mathrm{~cm}^{2}$ quartz filter was cut to analyse OC and EC using the Desert Research Institute (DRI) Model 2001 thermal/optical reflectance (TOR) carbon analyser (Atmoslytic Inc., Calabasas, CA, USA) with the Interagency Monitoring of Protected Visual Environment protocol. The samples were first heated at increasing temperatures under pure helium atmosphere, at $140^{\circ} \mathrm{C}, 280^{\circ} \mathrm{C}, 480^{\circ} \mathrm{C}$, and $580^{\circ} \mathrm{C}$ (for produce $\mathrm{OC} 1$, OC2, OC3, and OC4, respectively); and then at $580^{\circ} \mathrm{C}, 740{ }^{\circ} \mathrm{C}$, and $840{ }^{\circ} \mathrm{C}$ to determine EC1, EC2, and EC3 under a $2 \% \mathrm{O}_{2} / 98 \%$ He atmosphere. WSIs on the filters were extracted ultrasonically in $8 \mathrm{~mL}$ of ultrapure water, and the process was repeated four times. The extraction solutions were then combined while ensuring a constant volume of approximately $35 \mathrm{~mL}$ using ultrapure water. Finally, the WSIs were detected using ion chromatography (Dionex ICS3000, Dionex Ltd., Sunnyvale, California, USA). The WSIs included in this study were $\mathrm{NH}_{4}^{+}$, $\mathrm{K}^{+}, \mathrm{Cl}^{-}, \mathrm{NO}_{2}^{-}, \mathrm{NO}_{3}^{-}, \mathrm{SO}_{4}^{2-}, \mathrm{PO}_{4}^{3-}, \mathrm{F}^{-}$, and $\mathrm{Br}^{-}$. For elements, filters were first digested with purified nitric acid for $10 \mathrm{~h}$ at $120^{\circ} \mathrm{C}$, then, measured using inductively coupled plasma mass spectrometry (ICP-MS; ELANDRC II, PerkinElmer Ltd., Hong Kong). The target elements include $\mathrm{Na}, \mathrm{Mg}, \mathrm{K}, \mathrm{Ca}, \mathrm{Ti}, \mathrm{V}, \mathrm{Cr}, \mathrm{Mn}, \mathrm{Fe}, \mathrm{Cu}, \mathrm{Zn}$, and $\mathrm{Pb}$.

Quality assurance and control measures include filter duplicate and blank samples were examined for quality control. For OC and EC analysis, the duplicate samples were analysed after a batch of 10 samples to ensure that the error was within $5 \%$. The filter blanks were subtracted from samples for all water soluble ions and elements data detected in this study.

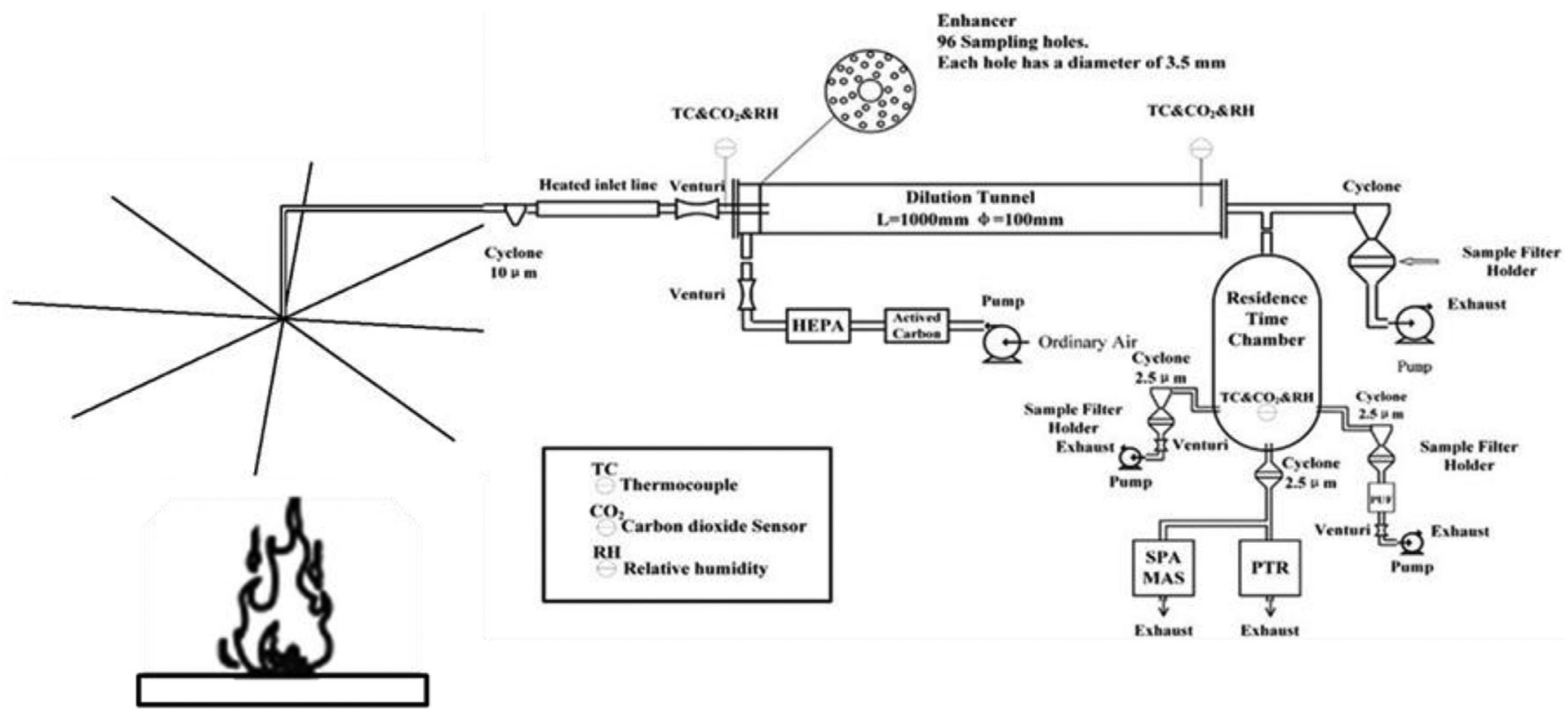

Fig. 1. Custom-made particulate matter sampling system. 


\subsection{Calculation}

\subsubsection{EFs}

The EFs of pollutants emitted from the burning of tropical rainforest vegetation were calculated by the carbon balance methods.

$\mathrm{C}_{\text {fuel }}-\mathrm{C}_{a s h}=\mathrm{R}_{F G} \times\left(\mathrm{c}\left(\mathrm{C}_{\mathrm{CO}_{2}}\right)+\mathrm{c}\left(\mathrm{C}_{C O}\right)+\mathrm{c}\left(\mathrm{C}_{O C}\right)+\mathrm{c}\left(\mathrm{C}_{E C}\right)\right)$

where $C_{\text {fuel }}$ and $C_{\text {ash }}$ represent the amount of carbon $\left(\mathrm{g} \mathrm{C} \mathrm{kg}^{-1}\right)$ in dry fuel and ash, respectively; $R_{F G}$ is the flue gas emission rate $\left(\mathrm{m}^{3} \mathrm{~kg}^{-1}\right.$ fuel); and $\mathrm{C}_{\mathrm{CO}_{2}}, \mathrm{C}_{\mathrm{CO}}, \mathrm{C}_{\mathrm{OC}}$, and $\mathrm{C}_{E C}$ represent the mass concentrations of carbon as $\mathrm{CO}_{2}, \mathrm{CO}, \mathrm{OC}$, and $\mathrm{EC}\left(\mathrm{g} \mathrm{C} \mathrm{m}^{-3}\right)$ in the flue gas, respectively. It should be noted that the concentration of $\mathrm{CO}$ was unavailable in this study because the $\mathrm{CO}$ sensor did not work well in the field work. In order to avoid overestimating $\mathrm{CO}$ emissions from forest burning, modified combustion efficiency (MCE) values reported by many other studies were reviewed and listed in Table S1. MCE value was calculated by $\mathrm{CO}_{2}$ concentration divided by sum concentrations of $\mathrm{CO}_{2}$ and $\mathrm{CO}$ $\left(\mathrm{MCE}=\mathrm{c}\left(\mathrm{CO}_{2}\right) /\left(\mathrm{c}\left(\mathrm{CO}_{2}\right)+\mathrm{c}(\mathrm{CO})\right)\right.$. As shown in Table S1, the MCE values reported by other studies ranged from 0.7 to 1 , with an average of $0.91 \pm 0.07$. Therefore, the average MCE $(0.91 \pm 0.07)$ value was used in this study to calculate the CO concentration. According to the equation of $\mathrm{MCE}, 10 \%$ of $\mathrm{CO}_{2}$ concentration was adopted for $\mathrm{CO}$ concentration finally.

Subsequently, the EFs of $\mathrm{CO}_{2}, \mathrm{PM}, \mathrm{OC}, \mathrm{EC}$, WSIs and elements were calculated by $R_{\mathrm{FG}}$. The details are available in Cui et al. (2017).

\subsubsection{Emissions amount}

Emission $=\sum_{\mathrm{i}}^{7} E F_{\mathrm{i}, \mathrm{t}} \times B_{\mathrm{i}, \mathrm{j}} \times F_{\mathrm{i}, \mathrm{j}}{ }^{*} C F_{\mathrm{i}}$

where $E F_{i, t}$ is the EF of pollutant $t$ for vegetation $i\left(\mathrm{~g} \mathrm{~kg}^{-1}\right.$ fuel), $B_{i, j}$ is the burned area of vegetation $i$ in pixel $j\left(\mathrm{~km}^{2}\right), F_{i, j}$ is the above ground biomass density for vegetation $i$ in pixel $j\left(\mathrm{~kg} \mathrm{~m}^{-2}\right)$; and $C F_{i}$ is the combustion factor for vegetation $i$.

The rainforest vegetation of interest in this study includes seven types: broadleaf evergreen forest, broadleaf deciduous forest, needle leaf evergreen forest, needle leaf deciduous forest, herbaceous (herbaceous and herbaceous with sparse trees), shrubs, and others (mixed forest, open trees, and sparse vegetation), according to the land cover data (version 3) from the Global Map database (https://globalmaps. github.io/). It should be noticed that the EFs used for vegetation designated as "others" were the average EFs for deciduous and evergreen forest plants in this study. Furthermore, the burned area data were from the MODIS active fire product (MCD45A1) with a resolution of $500 \mathrm{~m}$ (https://e4ft101.cr.usgs.gov/MOTA/). The burned area for each plant $i$ was determined by overlapping the MCD45A1 product with Global Map data. $F_{i, j}$ was determined using data reported by Chang and Song (2010). The reported combustion factors of different types of vegetation can vary greatly (Shi and Yamaguchi, 2014). Therefore, types of vegetation have been considered in $\mathrm{CF}$ value calculation this study. The values were acquired by reviewing studies about PM emission inventories (Jain et al., 2006; Shi et al., 2014). In this study, the $\mathrm{CF}_{\mathrm{i}}$ was $0.3 \pm 0.09,0.6 \pm 0.18$ and $0.9 \pm 027$ for coarse woodland, shrubs, and herbaceous vegetation, respectively.

\subsubsection{Uncertainty of emission}

The uncertainties of pollutant emissions were estimated base on the method of error transmission. Emission uncertainty is associated with EF, burned area, fuel load, and combustion factor, as described by Eq. (2).

$\mathrm{U}_{\mathrm{t}}^{2}=\sum \mathrm{U}_{\mathrm{ti}}^{2}$

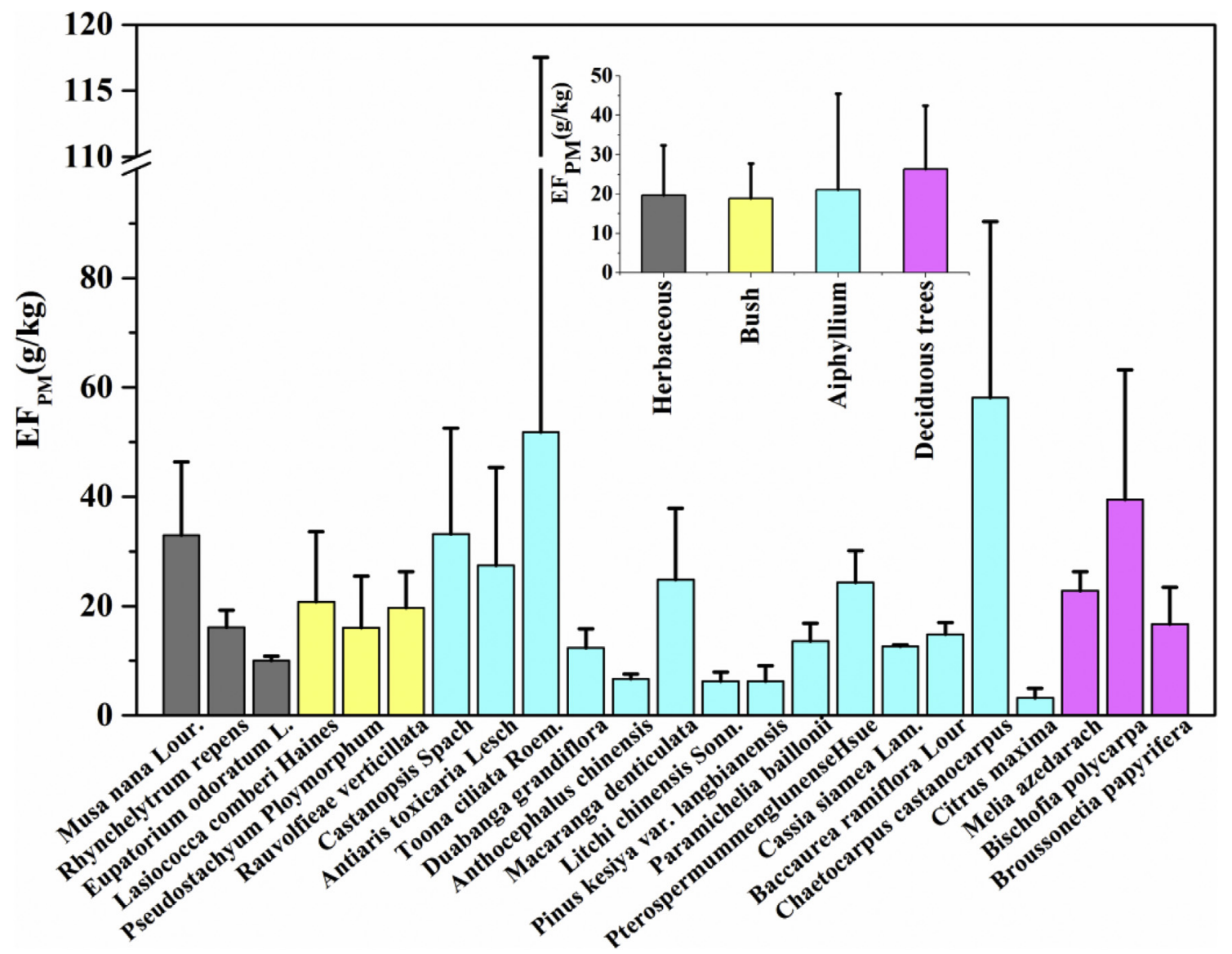

Fig. 2. Particulate matter (PM) emissions factors (EFs) from burning biomass from 23 rainforest plant species (error bar means standard deviation). 
$\left(\mathrm{U}_{\mathrm{ti}} / \text { Ave }_{\mathrm{ti}}\right)^{2}=\left(\mathrm{U}_{\mathrm{Ai}} / \text { Ave }_{\mathrm{Ai}}\right)^{2}+\left(\mathrm{U}_{\mathrm{EFi}} / \text { Ave }_{\mathrm{EFi}}\right)^{2}+\left(\mathrm{U}_{\mathrm{Fi}} / \text { Ave }_{\mathrm{Fi}}\right)^{2}+\left(\mathrm{U}_{\mathrm{Ci}} /\right.$ Ave $\left._{\mathrm{Ci}}\right)^{2}$

Where $U_{t}$ is the emission uncertainty of pollutant $t, U_{t i}$ is the emission uncertainty of pollutant $t$ for vegetation $i, U_{A i} / A e_{A i}$ is the ratio of standard deviation and average value of burned area for vegetation $\mathrm{i} ; \mathrm{U}_{\mathrm{EFi}} / \mathrm{Ave}_{\mathrm{EFi}}$ is the ratio of standard deviation and average value of emission factor for vegetation $i ; U_{\mathrm{Fi}} /$ Ave $_{\mathrm{Fi}}$ is the ratio of standard deviation and average value of above ground biomass density for vegetation $\mathrm{i} ; \mathrm{U}_{\mathrm{Ci}} /$ Ave $_{\mathrm{Ci}}$ is the ratio of standard deviation and average value of combustion factor for vegetation $i$.

\subsection{Statistical analysis}

All data statistical analysis was performed using Statistical Package for Social Science (version 16.0, SPSS, Inc.). The correlations between $\mathrm{EF}_{\mathrm{PM}}$ and humidity among evergreen trees, and between $\mathrm{EF}_{\mathrm{K}^{+}}$and $\mathrm{EF}_{\mathrm{K}}$ were determined using Pearson correlation. And Spearman's rank correlation was applied to investigate the correlations between fractions of WSIs for the 4 types of biomass. $\mathrm{p}<0.05$ was considered as statistically significant.

\section{Results and discussion}

\subsection{PM emission factors}

The EFs of PM emitted from the open burning of 23 different tropical plants are shown in Fig. 2 and Table 2. The overall average $\mathrm{EF}_{\mathrm{PM}}$ for these 23 species was $21.3 \pm 14.2 \mathrm{~g} \mathrm{~kg}^{-1}$ fuel, ranging from $3.23 \pm 1.62$ to $58.1 \pm 22.2 \mathrm{~g} \mathrm{~kg}^{-1}$ fuel. The highest average $\mathrm{EF}_{\mathrm{PM}}$ for the four vegetation subtypes was deciduous trees $\left(26.3 \pm 16.1 \mathrm{~g} \mathrm{~kg}^{-1}\right), \quad$ followed by evergreen trees (21.1 $\pm 24.4 \mathrm{~g} \mathrm{~kg}^{-1}$ fuel), herbaceous (19.7 $\pm 12.6 \mathrm{~g} \mathrm{~kg}^{-1}$ fuel), and shrubs (18.8 $\pm 8.87 \mathrm{~g} \mathrm{~kg}^{-1}$ fuel), which was associated with the extent of lignin content of the vegetation and the burning conditions. It was reported that higher lignin contents could make plants more toughness and stoutness, which accounted for $7.4 \%-12.2 \%$ of lignocellulose for herbaceous and $21 \%-25 \%$ for deciduous and evergreen trees (Guo et al., 2008; Yang, 2016). A wide range of $\mathrm{EF}_{\mathrm{PM}}$ was found for evergreen trees, which was probably due to a large variation in humidity among the trees (Pearson correlation between $\mathrm{EF}_{\mathrm{PM}}$ and humidity: $R=0.68$, $p<0.01$ ). The different $\mathrm{EF}_{\mathrm{PM}}$ of the four types of tropical forest vegetation in this study indicated that there was large uncertainty when only a single $\mathrm{EF}_{\mathrm{PM}}$ was used to represent all types of tropical forest vegetation. It has been reported that $\mathrm{EF}_{\mathrm{PM}}$ emitted from forest vegetation burning was 16 times higher than those from dambo grass (Aurell and Gullett, 2013; Sinha et al., 2003) and higher than those from other biomasses, such as extra-tropical forest and savanna grassland (Andreae and Merlet, 2001).

\subsection{Comparison of PM emission factors for different regions and burning methods}

Through comparison of different $\mathrm{EF}_{\mathrm{PM}}$ value reported in references, there were large differences in $\mathrm{EF}_{\mathrm{PM}}$ values depending on areas (etc. meteorological) and ways that biomass was burned. As shown in Fig. 3, the average $\mathrm{EF}_{\mathrm{PM}}$ was highest in the Southeast Asia, followed by North America, South America and Africa. Different average $\mathrm{EF}_{\mathrm{PM}}$ values were mainly attributed to diversity of wood species, discrepancy of ambient temperature and humidity. $\mathrm{EF}_{\mathrm{PM}}$ in Africa was the lowest mainly because the main biomass species is grass which could burn more sufficiently compare with other wood types. For further discussion of the $\mathrm{EF}_{\mathrm{PM}}$ difference in different regions, the average ambient temperature and humidity in the world since 1981 were acquired (see Figs. S1 and S2 in supporting information). It is hotter and dryer than other rainforest regions, which might lead higher combustion efficiency and therefore lower $\mathrm{EF}_{\mathrm{PM}}$. For North America, the $\mathrm{EF}_{\mathrm{PM}}$ values reported in literature vary greatly. The meteorological factor was one of the major reasons. In the Southeast Asia, both temperature and humidity are the highest, which could cause frequent forest fire and low combustion efficiency. Whenever forest fire occurs in the Southeast Asia, excessive PM emissions would be found, which cause severe environmental impacts. With comparison of results in different areas, it was confirmed that $\mathrm{PM}$ emissions would be largely underestimated when $\mathrm{EF}_{\mathrm{PM}}$ for Southeast Asia was replaced by other tropical rainforest regions.

As shown in Fig. 3, $\mathrm{EF}_{\mathrm{PM}}$ measured from laboratory experiments had the most varied values than those from ground-level and aircraft sampling. It was mainly attributed to the sharply changing modified combustion efficiency and different types of fuels used in laboratory experiments. McMeeking et al. (2009) indicated that higher fuel moisture could cause lower MCE and $\mathrm{EF}_{\mathrm{PM}}$ ranged from 4.2 to $52.2 \mathrm{~g} \mathrm{~kg}^{-1}$ fuel with MCE decreasing from 0.956 to 0.886 . The $\mathrm{EF}_{\mathrm{PM}}$ measured in this study ranks in the middle of the $\mathrm{EF}_{\mathrm{PM}}$ reported by previous laboratory studies. For two types of field measurements, namely ground-level and aircraft, $\mathrm{EF}_{\mathrm{PM}}$ obtained from ground-level measurements was significantly higher than those reported by aircraft sampling, which mainly be ascribed to different sampling locations. It was reported that the flaming smoke (MCE > 0.95) was inclined to spread to $3-4 \mathrm{~km}$ altitude due to the high temperature of flames (Alves et al., 2011). The vertical distances of sampling site from ground for ground-level measurements and aircraft sampling were always $2-3 \mathrm{~m}$ and $2-3 \mathrm{~km}$, respectively (Aurell and Gullett, 2013). Therefore, ground-level measurements seized surface ground PM most generating from smouldering phase $(\mathrm{MCE}<0.9)$ than those in aircraft sampling methods. But it should be noted that average PM emission factors obtained from laboratory experiments was consistent with those from field measurements because both flaming and smouldering phase were included in the entire lab experiments.

Table 2

Emission factors of PM and its constituents for 4 types of biomass (mg $\mathrm{kg}^{-1}$ fuel).

\begin{tabular}{|c|c|c|c|c|c|c|c|c|}
\hline & \multicolumn{2}{|c|}{ Herbaceous } & \multicolumn{2}{|c|}{ Brush } & \multicolumn{2}{|c|}{ Evergreen trees } & \multicolumn{2}{|c|}{ Deciduous trees } \\
\hline & Ave & SD & Ave & SD & Ave & SD & Ave & SD \\
\hline $\mathbf{P M}^{\mathrm{a}}$ & 19.7 & 12.6 & 18.8 & 8.87 & 21.1 & 24.4 & 26.3 & 16.1 \\
\hline $\mathrm{OC}^{\mathrm{a}}$ & 6.21 & 4.78 & 6.39 & 3.07 & 8.58 & 10.4 & 10.8 & 9.64 \\
\hline $\mathbf{E C}^{\mathrm{a}}$ & 1.00 & 0.38 & 1.13 & 0.64 & 1.13 & 0.90 & 1.27 & 0.99 \\
\hline $\mathrm{Na}$ & 4.21 & 7.29 & 11.2 & 15.8 & 10.1 & 21.2 & 9.10 & 15.8 \\
\hline Mg & 8.82 & 7.16 & 21.9 & 27.1 & 16.4 & 32.4 & 22.4 & 22.6 \\
\hline $\mathbf{K}$ & 412 & 474 & 119 & 90.6 & 92.0 & 103 & 177 & 149 \\
\hline $\mathrm{Ca}$ & 41.5 & 43.5 & 108 & 134 & 82.6 & 133 & 90.0 & 119 \\
\hline $\mathrm{Ti}$ & 0.51 & 0.89 & 1.75 & 2.15 & 2.07 & 4.31 & 2.04 & 2.98 \\
\hline V & 0.03 & 0.05 & 0.08 & 0.08 & 0.07 & 0.13 & 0.13 & 0.10 \\
\hline $\mathrm{Cr}$ & 1.26 & 1.87 & 0.35 & 0.31 & 0.37 & 0.49 & 1.15 & 0.84 \\
\hline Mn & 0.75 & 1.11 & 0.66 & 0.54 & 0.34 & 0.30 & 1.56 & 2.02 \\
\hline $\mathrm{Fe}$ & 15.4 & 20.4 & 40.3 & 47.3 & 23.1 & 49.8 & 24.2 & 14.5 \\
\hline $\mathrm{Cu}$ & 0.22 & 0.21 & 0.35 & 0.41 & 0.11 & 0.11 & 1.94 & 2.99 \\
\hline $\mathrm{Zn}$ & 2.51 & 3.97 & 22.0 & 37.5 & 6.07 & 13.3 & 11.8 & 9.58 \\
\hline $\mathbf{P b}$ & 0.14 & 0.14 & 0.37 & 0.25 & 0.20 & 0.31 & 0.20 & 0.21 \\
\hline $\mathbf{N H}_{4}^{+}$ & 7.84 & 13.6 & 0.00 & 0.00 & 0.88 & 3.29 & 253 & 438 \\
\hline $\mathbf{K}^{+}$ & 356 & 392 & 99.8 & 76.1 & 96.1 & 89.1 & 238 & 239 \\
\hline $\mathbf{P O}_{4}^{3-}$ & 22.6 & 39.2 & 13.5 & 23.4 & 79.0 & 153 & 25.0 & 43.3 \\
\hline $\mathrm{NO}_{2}^{-}$ & 20.8 & 32.3 & 3.77 & 6.54 & 1.92 & 5.69 & 0.00 & 0.00 \\
\hline $\mathbf{F}^{-}$ & 107 & 175 & 10.9 & 11.0 & 11.9 & 13.0 & 6.23 & 4.46 \\
\hline $\mathrm{Cl}^{-}$ & 198 & 125 & 393 & 556 & 39.6 & 31.7 & 701 & 1077 \\
\hline $\mathrm{Br}^{-}$ & 59.1 & 81.7 & 10.6 & 12.0 & 18.4 & 16.3 & 26.8 & 27.7 \\
\hline $\mathrm{NO}_{3}^{-}$ & 7.43 & 0.63 & 5.53 & 5.68 & 13.2 & 15.2 & 8.75 & 4.23 \\
\hline $\mathrm{SO}_{4}^{2-}$ & 163 & 174 & 127 & 163 & 85.2 & 83.6 & 103 & 137 \\
\hline
\end{tabular}

a: units ( $\mathrm{g} \cdot \mathrm{kg}^{-1}$ fuel). 

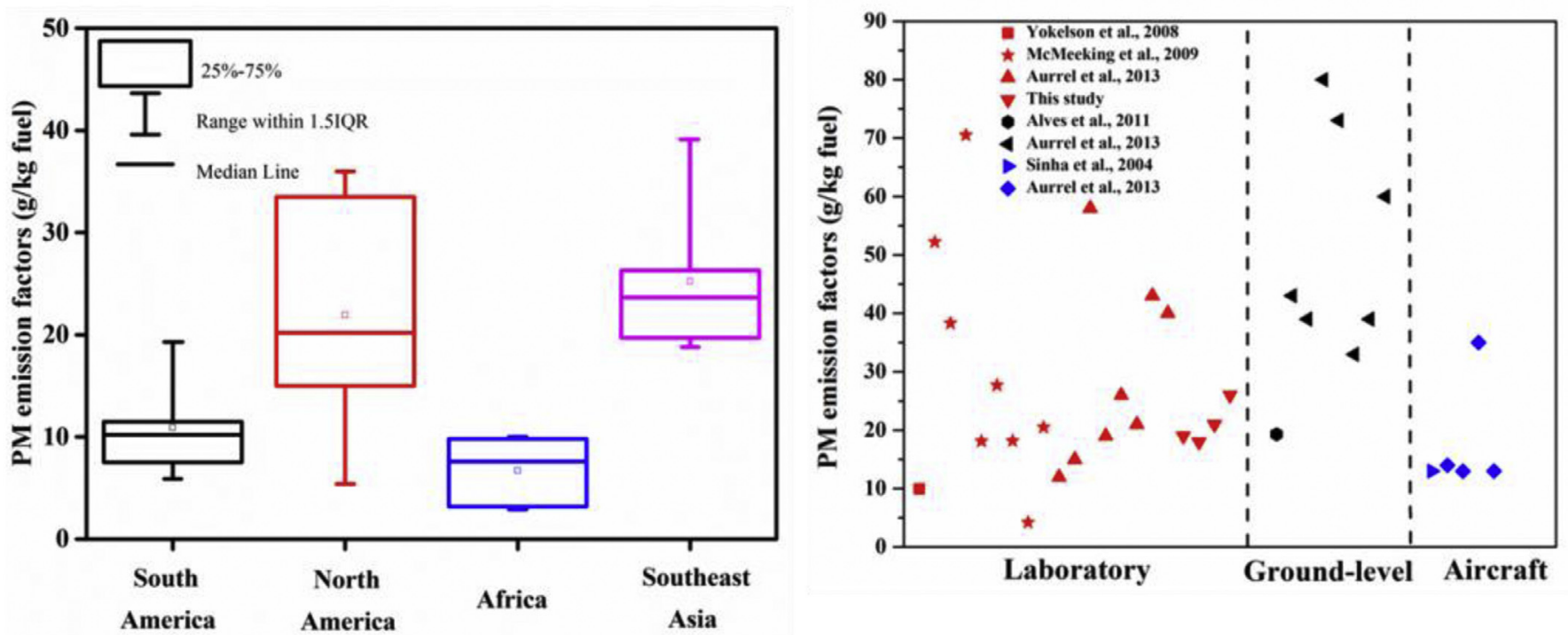

Fig. 3. Comparison of $\mathrm{EF}_{\mathrm{PM}}$ for different sampling regions and methods reported in different studies.

3.3. Characteristics of PM constituents from forest burning

Table 2 and Fig. S3 show the emission factors of PM constituents and PM mass balance for each type of biomass. The total amount of constituents analysed (organic matter $(\mathrm{OM})=1.6 \times$ OC, EC, WSIs, and elements) accounted for $66.5 \pm 19.2 \%$ of the total PM. The proportion of average PM chemical constituents from burning of tropical forest species in this study was similar to that reported by Alves et al. (2011) (e.g., carbonaceous components: $52 \pm 20 \%$; WSIs: $2.6 \%$; elements: $1.23 \%)$.
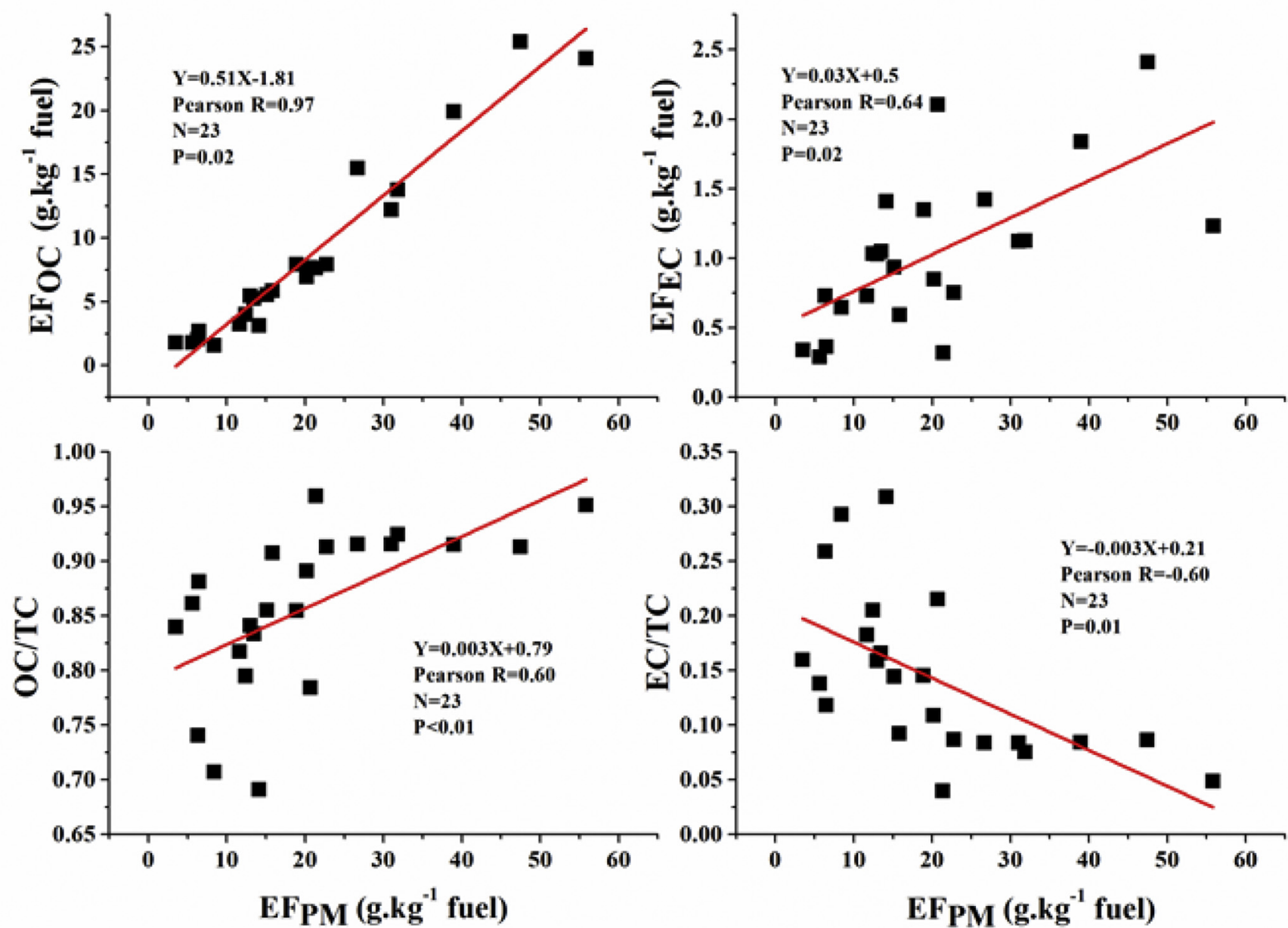

Fig. 4. Relationships among $\mathrm{EF}_{\mathrm{PM}}, \mathrm{EF}_{\mathrm{OC}}, \mathrm{EF}_{\mathrm{EC}}, \mathrm{OC} / \mathrm{TC}$, and $\mathrm{EC} / \mathrm{TC}$. 


\subsection{1. $O C$ and $E C$}

For the four types of tropical vegetation, the $\mathrm{EF}_{\mathrm{OC}}$ increased from $6.21 \mathrm{~g} \mathrm{~kg}^{-1}$ fuel (herbaceous) to $10.8 \mathrm{~g} \mathrm{~kg}^{-1}$ fuel (deciduous trees), and $\mathrm{EF}_{\mathrm{EC}}$ increased slightly from $0.998 \mathrm{~g} \mathrm{~kg}^{-1}$ fuel (herbaceous) to $1.27 \mathrm{~g} \mathrm{~kg}^{-1}$ fuel (deciduous trees). The trends of $\mathrm{EF}_{\mathrm{OC}}$ and $\mathrm{EF}_{\mathrm{EC}}$ from herbaceous to deciduous obtained in this study could be explained by the conclusion drawn by Alves et al. (2011), who found that $\mathrm{EF}_{\mathrm{OC}}$ increased considerably when the combustion conditions changed from flaming to smouldering, whereas $\mathrm{EF}_{\mathrm{EC}}$ seemed to stabilise between these two phases. Similarly, herbaceous vegetation is non-compact and easily combustible with $\mathrm{O}_{2}$, compared to compact deciduous trees, which could cause more frequently flame phase for herbaceous.

It was obvious that OM was the dominant constituent of PM from the 4 types of forest biomass burning, accounting for $56.9 \pm 18.0 \%$ of the PM mass. The proportion of OM to PM from burning tropical forest species in this study was similar to that reported by other studies (Ferek et al., 1998; Schmidl et al., 2008; Alves et al., 2011). The range of OC/ EC from the 23 tropical biomass species was from 2.41 to 24.0, and the variation of OC/EC ratios in this study was lower than that reported by Alves et al. (2011). Different pollutant EFs in this study might be attributed to thermodynamics, although the modified combustion efficiency (MCE) was not obtained. Generally, $\mathrm{EF}_{\mathrm{PM}}$ and $\mathrm{EF}_{\mathrm{OC}}$ increased with decreasing MCE values, while EC/TC values increased greatly at higher MCE values (Chen et al., 2007). As shown in Fig. 4, $\mathrm{EF}_{\mathrm{PM}}$ and $\mathrm{EF}_{\mathrm{OC}}, \mathrm{EF}_{\mathrm{PM}}$ and $\mathrm{EF}_{\mathrm{EC}}$, and $\mathrm{EF}_{\mathrm{PM}}$ and $\mathrm{OC} / \mathrm{TC}$ were significantly positively correlated, which indicated $\mathrm{EF}_{\mathrm{PM}}, \mathrm{EF}_{\mathrm{OC}}, \mathrm{EF}_{\mathrm{EC}}$ and $\mathrm{OC} / \mathrm{TC}$ were increased with MCE values. However, there was a significant negative correlation between $\mathrm{EF}_{\mathrm{PM}}$ and $\mathrm{EC} / \mathrm{TC}(p<0.05)$. These relationships might indicate that the high EFs and variations in OC/EC ratios are dependent on combustion processes.

\subsubsection{Water soluble ions}

The range of total WSIs emission factors was $92-3558 \mathrm{mg} \mathrm{kg}^{-1}$ fuel, with average of $598 \pm 820 \mathrm{mg} \mathrm{kg}^{-1}$ fuel, accounting for $0.49-9.0 \%$ of total PM. The average total EFs of WSIs in this study was obviously higher than the results reported by Sen et al. (2014) $\left(383 \pm 301 \mathrm{mg} \mathrm{kg}^{-1}\right.$ fuel) and Alves et al. (2011) (453 $\pm 504 \mathrm{mg} \mathrm{kg}^{-1}$ fuel). However, Alves only detected five ions, $\mathrm{K}^{+}$, $\mathrm{NH}_{4}^{+}, \mathrm{Cl}^{-}, \mathrm{SO}_{4}^{2-}$, and $\mathrm{NO}_{3}^{-}$, which was less than the quantity of ions detected in this study. When the other detected ions obtained in this study were added to calculate the amount of WSIs, the total $\mathrm{EF}_{\mathrm{WSIs}}$ in Alves's research could reach to $560 \mathrm{mg} \mathrm{kg}^{-1}$ fuel. For individual species of WSIs, the average EFs of $\mathrm{NH}_{4}{ }^{+}$for forest biomass burning in this study were in good agreement with those from Sen et al. (2014), and the average $\mathrm{EFs}$ of $\mathrm{K}^{+}$and $\mathrm{SO}_{4}^{2-}$ were consistent with those from Alves et al. (2011) (see Fig. 5). The $\mathrm{EF}$ of $\mathrm{Cl}^{-}$measured in this study was significantly higher than those reported by Alves et al. (2011) and Sen et al. (2014), while the EFs of $\mathrm{NO}_{2}{ }^{-}$and $\mathrm{NO}_{3}{ }^{-}$were lower than these references. Underestimated $\mathrm{EF}_{\mathrm{Cl}}{ }^{-}$in Alves et al. (2011) was caused by some extent from their low combustion temperature.

Fractions of water soluble ions to PM for 4 types of biomass are shown in Fig. $6 . \mathrm{Cl}^{-}, \mathrm{K}^{+}$, and $\mathrm{SO}_{4}^{2-}$ were the most abundant ions in most of the samples, whereas $\mathrm{NH}_{4}^{+}$level was the highest from deciduous trees burning. Except for deciduous trees, there were significant correlations of water soluble ions fractions between pairs of vegetation types, including herb, shrub and evergreen trees, indicating that the compositions of WSIs only varied slightly among the vegetation types. The different compositions of WSIs for deciduous trees from other rainforest biomass were mainly due to the habitat variation and the different abilities to absorb nutrients from the soil. $\mathrm{K}^{+}$emitted from biomass burning exhibited highly significant positive correlations $(p<0.01)$ with most of the anions, including $\mathrm{PO}_{4}^{3-}, \mathrm{F}^{-}, \mathrm{Cl}^{-} \mathrm{Br}^{-}$, and $\mathrm{SO}_{4}^{2-}$, which was consistent with results reported by Sen et al. (2014), who noted that $\mathrm{K}^{+}$was significantly correlated with $\mathrm{Cl}^{-}$and $\mathrm{SO}_{4}^{2-}$. Meanwhile, results by transmission electron microscopy demonstrated that crystal $\mathrm{KCl}$ and $\mathrm{K}_{2} \mathrm{SO}_{4}$ could be clearly seen in individual particles from biomass burning (Liu et al., 2017a, 2017b, 2017c). It is noted that $\mathrm{NH}_{4}^{+}$and $\mathrm{NO}_{3}^{-}$were not correlated with other ions, which might be attributed to complex combustion processes and detection limits for these two ions. The detection rates for $\mathrm{NH}_{4}^{+}$and $\mathrm{NO}_{3}^{-}$were $13 \%$ and $96 \%$, respectively. The detection limit for $\mathrm{NH}_{4}^{+}$in this study was $0.02 \mathrm{ppm}$, which caused several of $\mathrm{NH}_{4}^{+}$missing. However, the fraction of $\mathrm{NH}_{4}^{+}$was the highest for deciduous trees, different than those for other biomass. It was reported that less nitrogen accumulates as $\mathrm{NH}_{4}^{+}$ since $\mathrm{NH}_{4}^{+}$are oxidized to NOx at high temperature (Hegg et al., 1988; Alves et al., 2011).

As shown in Fig. 7, relative abundance of water soluble ions between Southeast Asia, North America, South America, Africa and Europe are compared. In general, $\mathrm{K}^{+}$and $\mathrm{Cl}^{-}$were the most abundant species in different regions. It was obviously that fraction of $\mathrm{K}^{+}$in Southeast Asia and North America was 30\% and 28\%, respectively, which was almost 2 times lower than those in Europe, while fractions of $\mathrm{Cl}^{-}$in Southeast Asia and North America were higher than those in other regions. For $\mathrm{SO}_{4}^{2-}$, fractions in different regions were consistent, ranged from $15 \%$ to $23 \%$. It should be noted that the fractions of $\mathrm{NO}_{3}^{-}$in Southeast Asia and Europe were negligible (2.2\% and 1.5\%) compared with other regions.

\subsubsection{Elements}

Total EFs of elements for herbaceous plants, shrubs, evergreen trees, and deciduous trees ranged from $233 \mathrm{mg} \mathrm{kg}^{-1}$ to $487 \mathrm{mg} \mathrm{kg}^{-1}$, accounting for $1.1-2.5 \%$ of the total PM. The variation in total EFs of elements in the four types of vegetation was relatively small. As shown in Fig. 6, K, Ca, Fe, Na, and Mg were the most abundant elements for almost all of the combusted forest vegetation, and the average of the sum of these five elements accounted for $95 \%$ of the total elements. Ribeiro et al. (2017) reported similar result that $\mathrm{Ca}, \mathrm{Na}$, and $\mathrm{Mg}$ were the dominant elements in three types of residual forest biomass burning emission. In addition, Corsini et al. (2017) measured elements (e.g., Al, $\mathrm{P}, \mathrm{Ti}, \mathrm{V}, \mathrm{Mn}, \mathrm{Fe}, \mathrm{Co}, \mathrm{Ni}, \mathrm{Cu}, \mathrm{Zn}, \mathrm{As}, \mathrm{Sr}, \mathrm{Mo}, \mathrm{Cd}, \mathrm{Ba}$, and $\mathrm{Pb}$ ) emitted from burning wood and found that Fe had the highest concentration. However, Ferek et al. (1998) reported that $\mathrm{Mn}, \mathrm{Cu}$, and $\mathrm{Zn}$ were the dominant elements emitted from savannah burning, which differed significantly from the results of this study. In addition, K emitted from rainforest burning in the present study was significantly correlated with $\mathrm{K}^{+}\left(R^{2}=0.91, p<0.01, \mathrm{n}=23\right)$, which was consistent with results reported by Chow et al. (2004).

The measurement of elemental emission from forest burning was very limited. Thus compositions of element in Fig. 7 were only available in three regions (i.e., Southeast Asia, Europe and South America). The results showed that Ca was the most abundant species in the Southeast

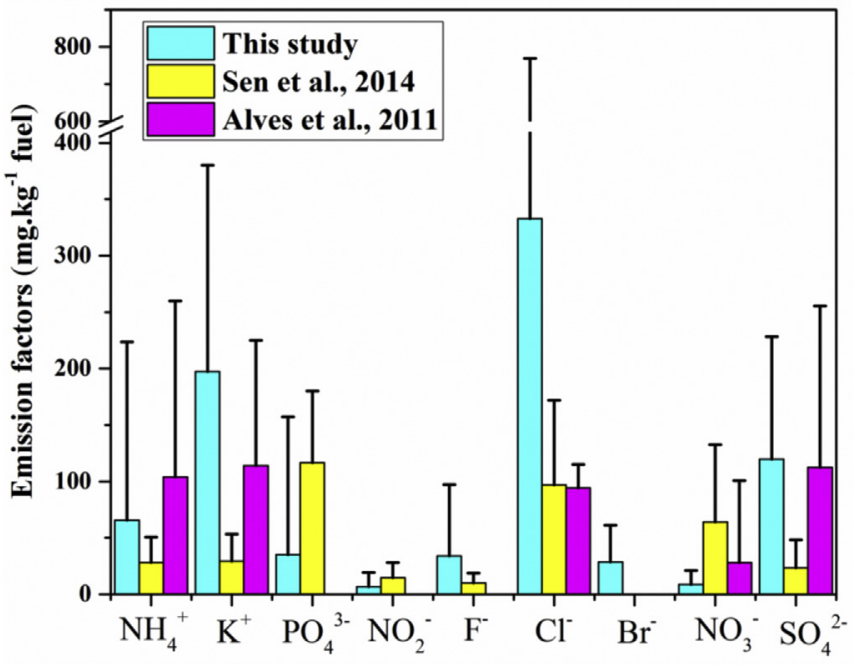

Fig. 5. Comparison of EFs in this study with those from previous study. 

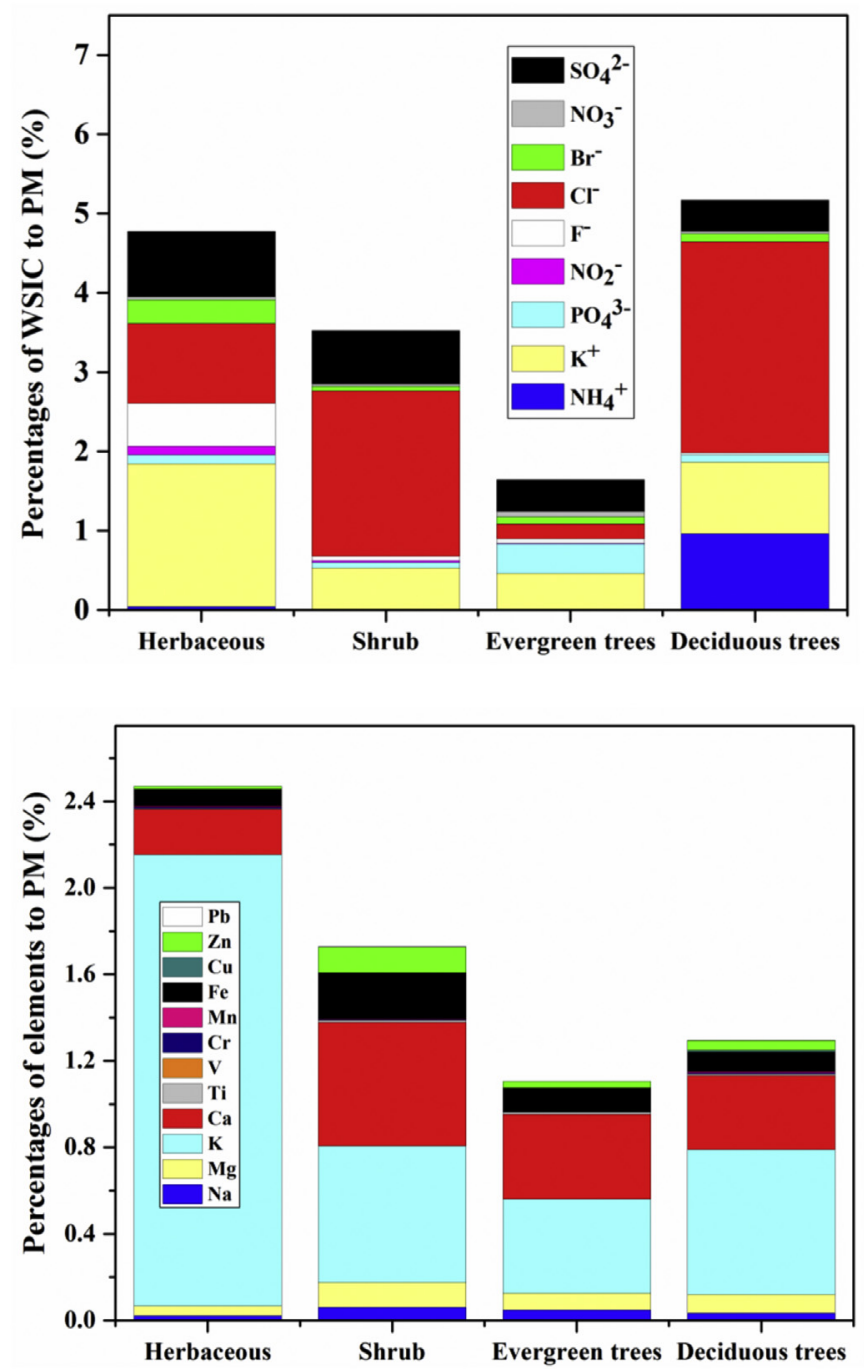

Fig. 6. Compositions of water soluble ions and elements for four types of biomass.
Asia and Europe. Furthermore, fractions of Fe and $\mathrm{Zn}$ in Southeast Asia were higher than those in Europe. In the South America, Fe accounted for almost $58 \%$ of the total elements ( $\mathrm{Ca}, \mathrm{Mg}$ and $\mathrm{Pb}$ was not detected), which was consistent with fraction of Fe in Southeast Asia.

\subsection{PM, OC, and EC emissions in the Southeast Asia}

The burned area of Southeast Asian rainforest in 2016 was derived by overlaying the burned area from the MODIS burned area product (MCD45A1) and corresponding land cover data. As shown in Fig. 8, the most significantly extensive forest burning occurred in Myanmar, Cambodia, and Thailand, accounting for almost 95\% of the total forest burned in the Southeast Asia. The main reason was that fire-related slash-and-burn agriculture and lands clearing by local farmers were dominant in these areas. Likewise, Shi et al. (2014) analysed biomass burned in the Southeast Asia from 2001 to 2010 using data from three frequent satellites and found that the more extensive burned areas in northern Southeast Asia were in Myanmar, northern Thailand, and eastern Cambodia, and the location of the most significant biomass burn in southern Southeast Asia was Indonesia. Indonesia has the largest peatland reserves in the world, and the extensive biomass burning was attributed to underground peatland burning, rather than to forest burning (Permadi and Nguyen Thi Kim, 2013; Shi et al., 2014; Shi and Yamaguchi, 2014). This may explain why no massive burned areas were detected in Indonesia in this study. As shown in Fig. 8, the annual emissions of PM, OC, and EC in 2016 in the Southeast Asia were 1780, 687 , and $86.1 \mathrm{Gg}$, respectively. The regions with significant emissions included Myanmar, Cambodia, and Thailand. The spatial distribution of pollutant emissions in this study was slightly different from those of the burned areas. For example, the country with the greatest area of burned forest was Myanmar, whereas the most significant pollutant emissions were found in Cambodia. This might be due to the forests in the different countries had different densities $\left(3.3 \mathrm{~kg} \mathrm{~km}^{-2}\right.$ in Myanmar and $5.7 \mathrm{~kg} \mathrm{~km}^{-2}$ in Cambodia), which indicated that in addition to burned area, forest density was another important factor influencing pollutant emissions.

The annual bottom-up emissions of PM, OC, and EC in the Southeast Asia have been estimated in several studies (Chang and Song, 2010; Shi and Yamaguchi, 2014). The annual PM emissions in the Southeast Asia estimated in this study was $1780 \mathrm{Gg}$, which was considerably lower than the emissions reported by Chang and Song (2010)

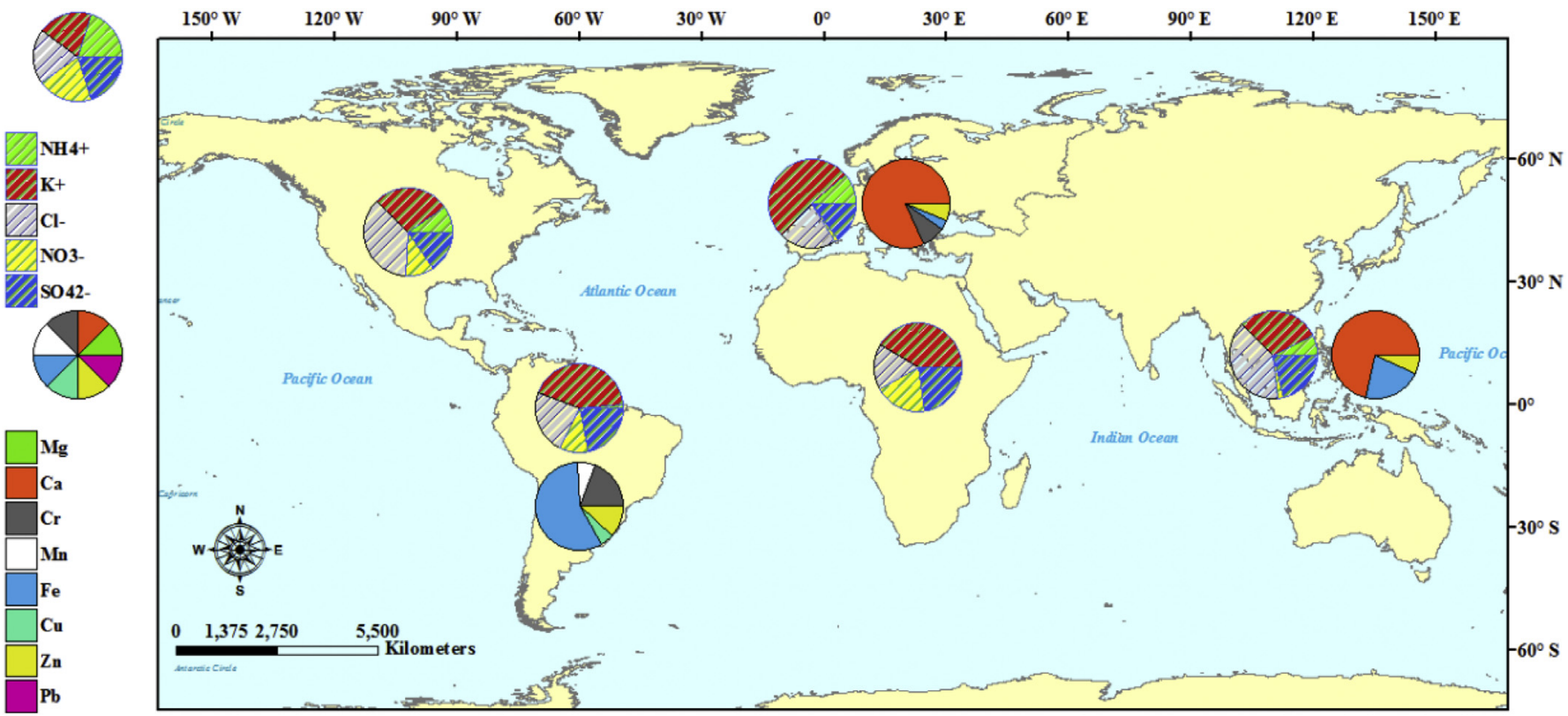

Fig. 7. Relative abundance of Elements and WSIs in PM emissions in representative rainforest regions. 


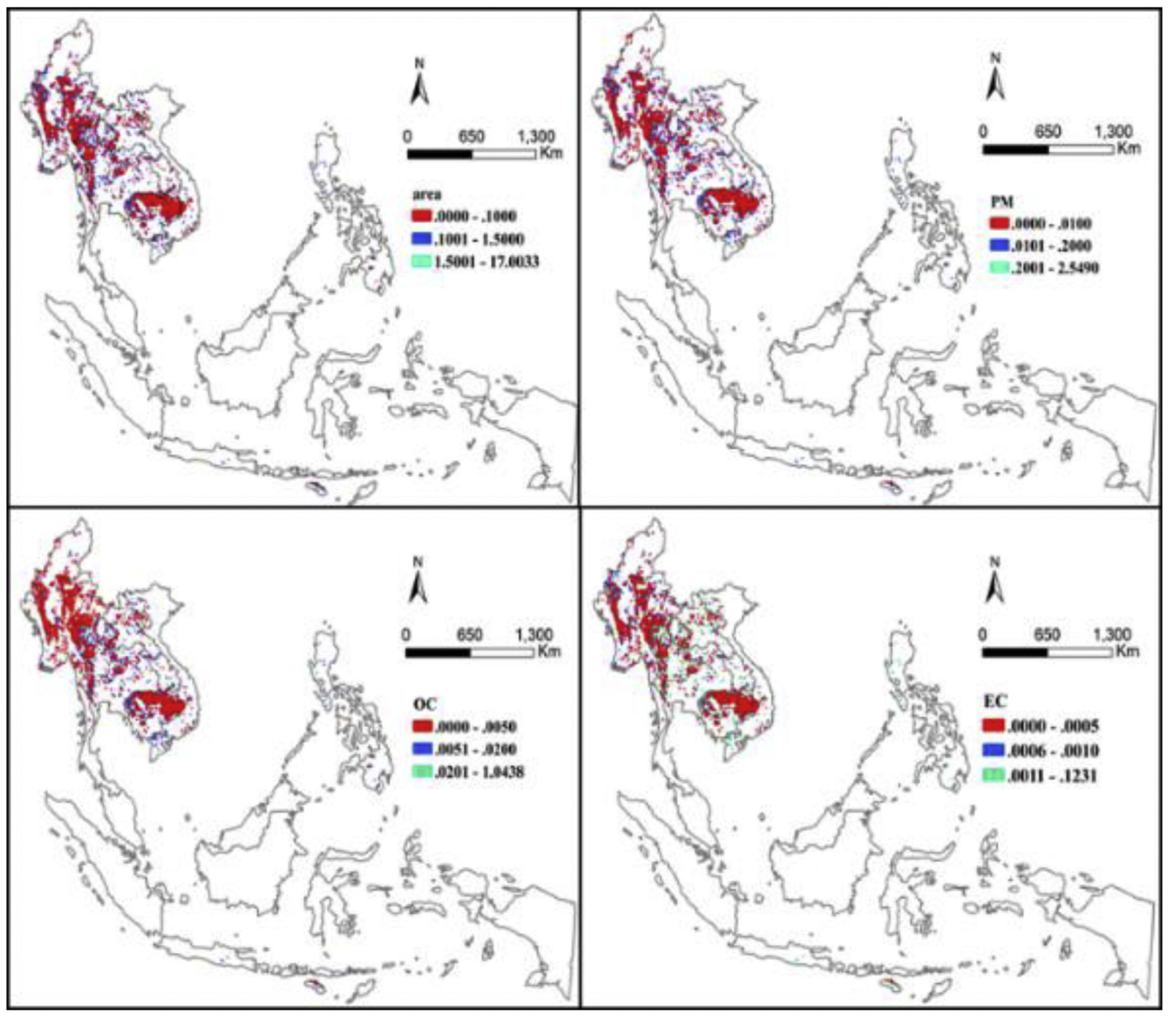

Fig. 8. Pollutant emissions from burning rainforest in Southeast Asia in 2016.

(2600-3700 Gg), Shi et al. (2014) (2237-3701 Gg) and GFEDv4.1 $(4780 \mathrm{Gg}$ ). Furthermore, the OC and EC emissions estimated in this study were within the range of data reported by other studies. The different pollutant emissions were related to several factors when accounting for various algorithms and data sources, such as differences in burned area, EFs, and biomass density. The necessary parameters to estimate pollutant emissions, including research area, research year, EFs, and burned area, are compiled in Table S2. It should be noted that the biomass densities and combustion factors are not shown in Table S2 as these data were not available in the studies we reviewed. Similar to $\mathrm{PM}$ emissions, we found that the research area and $\mathrm{EF}_{\mathrm{PM}}$ in this study were also lower than those used by Chang and Song (2010). Except for the countries we studied, India, Maldives, Sri Lanka, Nepal, Bhutan, and Bangladesh were assessed by Chang and Song (2010). As a result, the burned area in this study $\left(14,657 \mathrm{~km}^{2}\right)$ was smaller than that in Chang and Song (2010) $\left(23,876 \mathrm{~km}^{2}\right)$. Furthermore, the $\mathrm{EF}_{\mathrm{PM}}$ cited from Chang and Song (2010) was measured in 2001 by Andreae and Merlet (2001), and was three times higher than the values in our study in 2016, leading to the resultant higher annual PM emissions. The EFs of OC and EC used by Chang and Song (2010) were 6.8 and $0.66 \mathrm{~g} \mathrm{~kg}^{-1}$ fuel, respectively. However, it is unlikely that the total EFs of OC and EC accounted for only $17.2 \%$ of the total PM. The annual emissions of PM, OC, and EC in GFEDv4.1 were higher than those reported by Chang and Song (2010), although the research area was similar in those two studies. These differences might be attributed to overestimation of burned area by GFEDv4.1. The MODIS 500-m burned area product is reportedly more accurate than the GFED3 burned area product, with $0.5^{\circ} \times 0.5^{\circ}$ spatial resolution (Shi and Yamaguchi, 2014).

The intra-annual burned forest area, PM, OC, and EC emissions in Southeast Asia were shown in Table 3. The most extensive forest fires occurred during the four-month period from January to April, accounting for $99.5 \%$ of the total forest fires in 2016 , which was consistent with results reported by Giglio et al. (2013) and Fu et al. (2012). Climate and agricultural activities were the two main reasons of temporal variations. January to March is the typical fire season. The monsoon season begins in May and lasts for at least four months, which can bring heavy rain. In addition, clearing land with fire before spring cultivation is an important activity for local farmers. Similar to spatial characteristics, trends of monthly variations in PM, OC and EC emissions differed slightly. For example, the area of burned forest and PM 
Table 3

Intra-annual pollutant emissions from rainforest burning in Southeast Asia (Gg).

\begin{tabular}{lllll}
\hline Month & Area burned $\left(\mathrm{km}^{2}\right)$ & PM & OC & EC \\
\hline January & 4044 & 555 & 227 & 28.8 \\
February & 4605 & 635 & 218 & 27.4 \\
March & 4901 & 475 & 194 & 24.0 \\
April & 1031 & 107 & 43.7 & 5.47 \\
May & 33.0 & 4.36 & 1.94 & 0.228 \\
June & 1.16 & 0.178 & 0.07 & 0.010 \\
July & 2.38 & 0.259 & 0.10 & 0.014 \\
August & 8.89 & 1.15 & 0.46 & 0.062 \\
September & 8.23 & 1.20 & 0.48 & 0.065 \\
October & 0.204 & 0.041 & 0.02 & 0.002 \\
November & 1.68 & 0.026 & 0.05 & 0.001 \\
December & 19.5 & 0.424 & 1.13 & 0.057 \\
Total & $\mathbf{1 4 6 5 7}$ & $\mathbf{1 7 8 0}$ & $\mathbf{6 8 7}$ & $\mathbf{8 6}$ \\
\hline
\end{tabular}

emissions reached their maximums in March, whereas peak values for OC and EC occurred in January. The different temporal variations of PM, OC, and EC due to the different EFs of the four types of tropical rainforest vegetation examined in this study were another important factor affecting pollutant emissions.

\subsection{Emission uncertainties}

The uncertainty of satellite data might be resulted from the persistent cloud cover, small fire, and short duration and so on (Benali et al., 2016). In order to be more precise, we assumed that the total uncertainty from MODIS burned-area product was $20 \%$ which was reported by Hyer and Reid (2009). The standard deviations of mean values for $\mathrm{EF}_{\mathrm{PM}}, \mathrm{EF}_{\mathrm{OC}}$, and $\mathrm{EF}_{\mathrm{EC}}$ measured in this study were $66.7 \%$, $89.8 \%$, and $60.8 \%$ for forest burning, respectively. The standard deviations of mean values for $\mathrm{EF}_{\mathrm{PM}}, \mathrm{EF}_{\mathrm{OC}}$, and $\mathrm{EF}_{\mathrm{EC}}$ were $47.2 \%, 48.1 \%$ and $57.5 \%$ for shrub. The standard deviations of mean values for $\mathrm{EF}_{\mathrm{PM}}$, $\mathrm{EF}_{\mathrm{OC}}$, and $\mathrm{EF}_{\mathrm{EC}}$ were $64.0 \%, 77.1 \%$ and $37.6 \%$ for herbaceous. In addition, the combustion factor varied significantly by fuel types and moisture content (Goto and Suzuki, 2013). Thus, we assumed that the uncertainty of the combustion factor was about $30 \%$ by combing the combustion factors reported by Jain et al. (2006) and in this study. Finally, the estimated emissions (minimum-maximum) ranged from 1527 to $2834 \mathrm{Gg} \mathrm{year}^{-1}$ for PM, 529.9-1100 $\mathrm{Gg} \mathrm{year}^{-1}$ for OC, and 81.02-150.4 Gg year $^{-1}$ for EC.

\section{Conclusions}

In this study, EFs of PM, OC, EC, WSIs, and elements from rainforest burning in Southeast Asian were measured. Simultaneously, average $\mathrm{EF}_{\mathrm{PM}}$ for different biomass types, sampling regions and burning methods were compared. The average $\mathrm{EF}_{\mathrm{PM}}$ was the highest in Southeast Asia, followed by North America, South America and Africa, which was mainly attributed to the diversity of wood species, discrepancy of ambient temperature and humidity. The findings from this study indicate that using of $\mathrm{EF}_{\mathrm{PM}}$ from other regions would lead to underestimation of PM emissions in Southeast Asia.

OM was the dominant constituent of PM from the biomass burning emissions in the Southeast Asia, accounting for $56.9 \pm 18.0 \%$ of the total PM mass. $\mathrm{K}^{+}, \mathrm{Cl}^{-}$, and $\mathrm{SO} 2-4$ were the most abundant ions in most of the samples. Notably, $\mathrm{K}^{+}$emitted from biomass burning exhibited the most significant positive correlations $(p<0.01)$ with PO3$4, \mathrm{~F}^{-}, \mathrm{Cl}^{-}, \mathrm{Br}^{-}$, and $\mathrm{SO} 2-4$, consistent with levels reported in other studies. $\mathrm{K}, \mathrm{Ca}, \mathrm{Fe}, \mathrm{Na}$, and $\mathrm{Mg}$ were the most abundant elements in almost all emissions from the burned forest vegetation. Furthermore, source profiles of WSIs and elements varied largely in different areas.

The PM, OC, and EC emissions from rainforest burning in Southeast Asia in 2016 were estimated. PM emissions reached to its maximum in March, whereas OC and EC emissions levels peaked in January.

\section{Acknowledgements}

This study was supported by the Natural Scientific Foundations of China (Nos. 41430645, 91744203 and 41473091, 41430646, 41375125).

\section{Appendix A. Supplementary data}

Supplementary data related to this article can be found at https:// doi.org/10.1016/j.atmosenv.2018.07.062.

\section{References}

Akagi, S.K., Yokelson, R.J., Wiedinmyer, C., Alvarado, M.J., Reid, J.S., Karl, T., Crounse, J.D., Wennberg, P.O., 2011. Emission factors for open and domestic biomass burning for use in atmospheric models. Atmos. Chem. Phys. 11 (9), 4039-4072.

Alves, C., Vicente, A., Nunes, T., Goncalves, C., Fernandes, A.P., Mirante, F., Tarelho, L., de la Campa, A.M.S., Querol, X., Caseiro, A., Monteiro, C., Evtyugina, M., Pio, C., 2011. Summer 2009 wildfires in Portugal: emission of trace gases and aerosol composition. Atmos. Environ. 45 (3), 641-649.

Amaral, S.S., de Carvalho, J.A., Costa, M.A.M., Pinheiro, C., 2016. Particulate matter emission factors for biomass combustion. Atmosphere 7 (11), 25.

Andreae, M.O., Merlet, P., 2001. Emission of trace gases and aerosols from biomass burning. Global Biogeochem. Cycles 15 (4), 955-966.

Aurell, J., Gullett, B.K., 2013. Emission factors from aerial and ground measurements of field and laboratory forest burns in the southeastern US: $\mathrm{PM}_{2.5}$, black and Brown carbon, VOC, and PCDD/PCDF. Environ. Sci. Technol. 47 (15), 8443-8452.

Benali, A., Russo, A., Sa, A.C.L., Pinto, R.M.S., Price, O., Koutsias, N., Pereira, J.M.C., 2016. Determining fire dates and locating ignition points with satellite data. Rem. Sens. 8 (4), 20.

Burgess, M., Hillers, A., Bannah, D., Mohamed, S., Swaray, M., Turay, B.S., Vickery, J., Lindsell, J., 2017. The importance of protected and unprotected areas for colony occupancy and colony size in White-necked Picathartes Picathartes gymnocephalus in and around Gola Rainforest National Park, Sierra Leone. Bird. Conserv. Int. 27 (2), 244-255.

Chaiyo, U., Garivait, S., 2014. Estimation of black carbon emissions from dry dipterocarp forest fires in Thailand. Atmosphere 5 (4), 1002.

Chan, K.L., 2017. Biomass burning sources and their contributions to the local air quality in Hong Kong. Sci. Total Environ. 596-597, 212-221.

Chan, K.L., Chan, K.L., 2017. Aerosol optical depths and their contributing sources in Taiwan. Atmos. Environ. 148, 364-375.

Chang, D., Song, Y., 2010. Estimates of biomass burning emissions in tropical Asia based on satellite-derived data. Atmos. Chem. Phys. 10 (5), 2335-2351.

Chen, L.W.A., Moosmüller, H., Arnott, W.P., Chow, J.C., Watson, J.G., Susott, R.A., Babbitt, R.E., Wold, C.E., Lincoln, E.N., Hao, W.M., 2007. Emissions from laboratory combustion of wildland Fuels: emission factors and source profiles. Environ. Sci. Technol. 41 (12), 4317-4325.

Chow, J.C., Watson, J.G., Kuhns, H., Etyemezian, V., Lowenthal, D.H., Crow, D., Kohl, S.D., Engelbrecht, J.P., Green, M.C., 2004. Source profiles for industrial, mobile, and area sources in the big bend regional aerosol visibility and observational study. Chemosphere 54 (2), 185-208.

Chow, J.C., Watson, J.G., Lowenthal, D.H., Antony Chen, L.W., Motallebi, N., 2011. $\mathrm{PM}_{2.5}$ source profiles for black and organic carbon emission inventories. Atmos. Environ. 45 (31), 5407-5414.

Christian, T.J., Kleiss, B., Yokelson, R.J., Holzinger, R., Crutzen, P.J., Hao, W.M., Saharjo, B.H., Ward, D.E., 2003. Comprehensive laboratory measurements of biomass-burning emissions: 1. Emissions from Indonesian, African, and other fuels. J. Geophys. Res.: Atmosphere 108 (D23).

Corsini, E., Vecchi, R., Marabini, L., Fermo, P., Becagli, S., Bernardoni, V., Caruso, D., Corbella, L., Dell'Acqua, M., Galli, C.L., Lonati, G., Ozgen, S., Papale, A., Signorini, S. Tardivo, R., Valli, G., Marinovich, M., 2017. The chemical composition of ultrafine particles and associated biological effects at an alpine town impacted by wood burning. Sci. Total Environ. 587-588, 223-231.

Cui, M., Chen, Y., Feng, Y., Li, C., Zheng, J., Tian, C., Yan, C., Zheng, M., 2017. Measurement of PM and its chemical composition in real-world emissions from nonroad and on-road diesel vehicles. Atmos. Chem. Phys. 17 (11), 6779-6795.

Cui, M., Chen, Y., Tian, C., Zhang, F., Yan, C., Zheng, M., 2016. Chemical composition of $\mathrm{PM}_{2.5}$ from two tunnels with different vehicular fleet characteristics. Sci. Total Environ. 550, 123-132.

Duncan, B., Martin, R., Staudt, A., Yevich, R., Logan, J., 2003. Interannual and seasonal variability of biomass burning emissions constrained by satellite observations. J. Geophys. Res. Atmos. 108 (D2), 28.

Ferek, R.J., Reid, J.S., Hobbs, P.V., Blake, D.R., Liousse, C., 1998. Emission factors of hydrocarbons, halocarbons, trace gases and particles from biomass burning in Brazil J. Geophys. Res.: Atmosphere 103 (D24), 32107-32118.

Fu, J.S., Hsu, N.C., Gao, Y., Huang, K., Li, C., Lin, N.H., Tsay, S.C., 2012. Evaluating the influences of biomass burning during 2006 BASE-ASIA: a regional chemical transport modeling. Atmos. Chem. Phys. 12 (9), 3837-3855.

Giglio, L., Randerson, J.T., van der Werf, G.R., 2013. Analysis of daily, monthly, and annual burned area using the fourth-generation global fire emissions database (GFED4). J. Geophys. Res. Biogeosci. 118 (1), 317-328.

Goto, Y., Suzuki, S., 2013. Estimates of carbon emissions from forest fires in Japan, 
1979-2008. Int. J. Wildland Fire 22 (6), 721-729.

Guo, X.H., Yu, D.S., Wang, J., Tang, D.Y., Liu, X.M., 2008. Comparative study of the lignocellulose content in Six plants. J. Hunan Univ. (Nat. Sci) (09), 76-78.

Hegg, D.A., Radke, L.F., Hobbs, P.V., Riggan, P.J., 1988. Ammonia emissions from biomass burning. Geophys. Res. Lett. 15 (4), 335-337.

Hsieh, Y.P., Bugna, G., Robertson, K., 2016. Examination of two assumptions commonly used to determine $\mathrm{PM}_{2.5}$ emission factors for wildland fires. Atmos. Environ. 147, 274-283.

Hyer, E.J., Reid, J.S., 2009. Baseline uncertainties in biomass burning emission models resulting from spatial error in satellite active fire location data. Geophys. Res. Lett. 36,5 .

Jain, A.K., Tao, Z.N., Yang, X.J., Gillespie, C., 2006. Estimates of global biomass burning emissions for reactive greenhouse gases (CO, NMHCs, and NOx) and $\mathrm{CO}_{2}$. J. Geophys. Res. Atmos. 111 (D6), 14.

Jian, Y., Fu, T.M., 2014. Injection heights of springtime biomass-burning plumes over peninsular Southeast Asia and their impacts on long-range pollutant transport. Atmos. Chem. Phys. 14 (8), 3977-3989.

Lee, H.H., Bar-Or, R.Z., Wang, C., 2017. Biomass burning aerosols and the low-visibility events in Southeast Asia. Atmos. Chem. Phys. 17 (2), 965-980.

Liu, L., Kong, S., Zhang, Y., Wang, Y., Xu, L., Yan, Q., Lingaswamy, A.P., Shi, Z., Lv, S., Niu, H., Shao, L., Hu, M., Zhang, D., Chen, J., Zhang, X., Li, W., 2017a. Morphology, composition, and mixing state of primary particles from combustion sources - crop residue, wood, and solid waste. Sci. Rep. 7 (1), 5047.

Liu, S., Yin, Y., Liu, X., Cheng, F., Yang, J., Li, J., Dong, S., Zhu, A., 2017b. Ecosystem Services and landscape change associated with plantation expansion in a tropical rainforest region of Southwest China. Ecol. Model. 353, 129-138.

Liu, X., Huey, L.G., Yokelson, R.J., Selimovic, V., Simpson, I.J., Müller, M., Jimenez, J.L., Campuzano-Jost, P., Beyersdorf, A.J., Blake, D.R., Butterfield, Z., Choi, Y., Crounse, J.D., Day, D.A., Diskin, G.S., Dubey, M.K., Fortner, E., Hanisco, T.F., Hu, W., King, L.E., Kleinman, L., Meinardi, S., Mikoviny, T., Onasch, T.B., Palm, B.B., Peischl, J., Pollack, I.B., Ryerson, T.B., Sachse, G.W., Sedlacek, A.J., Shilling, J.E., Springston, S., Clair, J. M. St, Tanner, D.J., Teng, A.P., Wennberg, P.O., Wisthaler, A., Wolfe, G.M., 2017c. Airborne measurements of western U.S. wildfire emissions: comparison with prescribed burning and air quality implications. J. Geophys. Res.: Atmosphere 122 (11), 6108-6129.

McMeeking, G.R., Kreidenweis, S.M., Baker, S., Carrico, C.M., Chow, J.C., Collett, J.L., Hao, W.M., Holden, A.S., Kirchstetter, T.W., Malm, W.C., Moosmüller, H., Sullivan, A.P., Wold, C.E., 2009. Emissions of trace gases and aerosols during the open combustion of biomass in the laboratory. J. Geophys. Res. Atmosphere 114 (D19).
Permadi, D.A., Nguyen Thi Kim, O., 2013. Assessment of biomass open burning emissions in Indonesia and potential climate forcing impact. Atmos. Environ. 78, 250-258.

Reddington, C.L., Yoshioka, M., Balasubramanian, R., Ridley, D., Toh, Y.Y., Arnold, S.R., Spracklen, D.V., 2014. Contribution of vegetation and peat fires to particulate air pollution in Southeast Asia. Environ. Res. Lett. 9 (9), 12.

Ribeiro, J.P., Vicente, E.D., Alves, C., Querol, X., Amato, F., Tarelho, L.A.C., 2017. Characteristics of ash and particle emissions during bubbling fluidised bed combustion of three types of residual forest biomass. Environ. Sci. Pollut. Control Ser. 24 (11), 10018-10029.

Schmidl, C., Bauer, H., Dattler, A., Hitzenberger, R., Weissenboeck, G., Marr, I.L., Puxbaum, H., 2008. Chemical characterisation of particle emissions from burning leaves. Atmos. Environ. 42 (40), 9070-9079.

Sen, A., Mandal, T.K., Sharma, S.K., Saxena, M., Gupta, N.C., Gautam, R., Gupta, A., Gill, T., Rani, S., Saud, T., Singh, D.P., Gadi, R., 2014. Chemical properties of emission from biomass fuels used in the rural sector of the western region of India. Atmos. Environ. 99, 411-424.

Shi, Y., Sasai, T., Yamaguchi, Y., 2014. Spatio-temporal evaluation of carbon emissions from biomass burning in Southeast Asia during the period 2001-2010. Ecol. Model. $272,98-115$.

Shi, Y., Yamaguchi, Y., 2014. A high-resolution and multi-year emissions inventory for biomass burning in Southeast Asia during 2001-2010. Atmos. Environ. 98, 8-16.

Sinha, P., Hobbs, P.V., Yokelson, R.J., Bertschi, I.T., Blake, D.R., Simpson, I.J., Gao, S., Kirchstetter, T.W., Novakov, T., 2003. Emissions of trace gases and particles from savanna fires in southern Africa. J. Geophys. Res.: Atmosphere 108 (D13).

Streets, D.G., Yarber, K.F., Woo, J.H., Carmichael, G.R., 2003. Biomass burning in Asia: annual and seasonal estimates and atmospheric emissions. Global Biogeochem. Cycles 17 (4), 20.

Watson, J.G., Chow, J.C., Houck, J.E., 2001. $\mathrm{PM}_{2.5}$ chemical source profiles for vehicle exhaust, vegetative burning, geological material, and coal burning in Northwestern Colorado during 1995. Chemosphere 43 (8), 1141-1151.

Yang, Y.J., 2016. Study on the Root Tensie Properties and the Soil Shear Properties of Typical Tree Species in North China. Beijing Forestry University.

Zhang, Y., Kang, S., Cong, Z., Schmale, J., Sprenger, M., Li, C., Yang, W., Gao, T., Sillanpää, M., Li, X., Liu, Y., Chen, P., Zhang, X., 2017. Light-absorbing impurities enhance glacier albedo reduction in the southeastern Tibetan plateau. J. Geophys. Res.: Atmosphere 122 (13), 6915-6933.

Zong, Z., Chen, Y.J., Tian, C.G., Fang, Y., Wang, X.P., Huang, G.P., Zhang, F., Li, J., Zhang, G., 2015. Radiocarbon-based impact assessment of open biomass burning on regional carbonaceous aerosols in North China. Sci. Total Environ. 518, 1-7. 